\title{
Transplanted Oligodendrocyte Progenitor Cells Expressing a Dominant-Negative FGF Receptor Transgene Fail to Migrate In Vivo
}

\author{
Donna J. Osterhout, ${ }^{1}$ Sylvie Ebner, ${ }^{1}$ Jingsong Xu, ${ }^{2}$ David M. Ornitz, ${ }^{2}$ George A. Zazanis, ${ }^{1}$ and \\ Randall D. McKinnon ${ }^{1}$ \\ ${ }^{1}$ Division of Neurosurgery, Department of Surgery, University of Medicine and Dentistry of New Jersey, Robert Wood \\ Johnson Medical School, Piscataway, New Jersey 08854, and 2Department of Molecular Biology and Pharmacology, \\ Washington University Medical School, St. Louis, Missouri 63110
}

The proliferation, migration, survival, and differentiation of oligodendrocyte progenitor cells, precursors to myelin-forming oligodendrocytes in the CNS, are controlled by a number of polypeptide growth factors in vitro. The requirement and roles for individual factors in vivo, however, are primarily unknown. We have used a cell transplantation approach to examine the role of fibroblast growth factor (FGF) in oligodendrocyte development in vivo. A dominant-negative version of the FGF receptor-1 transgene was introduced into oligodendrocyte progenitors in vitro, generating cells that were nonresponsive to
FGF but responsive to other mitogens. When transplanted into the brains of neonatal rats, mutant cells were unable to migrate and remained within the ventricles. These results suggest a role for FGF signaling in establishing a motile phenotype for oligodendrocyte progenitor cell migration in vivo and illustrate the utility of a somatic cell mutagenesis approach for the study of gene function during CNS development in vivo.

Key words: CNS development; myelin; oligodendrocyte; O-2A progenitor; transplantation; migration; fibroblast growth factor receptor; dominant-negative
Oligodendrocytes, the myelinating cells of the CNS, are generated from progenitor cells that arise in the subventricular zone and then migrate through the brain parenchyma into axonal tracts and gray matter (Hardy and Reynolds, 1991; Levison et al., 1993; Price, 1994). These migratory precursors arise at embryonic day 12-14 in the rat spinal cord (Noll and Miller, 1993; Timsit et al., 1995) from neuroectodermal cells positioned throughout the rostral-caudal neural axis (Hardy and Friedrich, 1996) and are thought to originate in the ventral-lateral portion of the neural tube (Pringle and Richardson, 1993; Miller, 1996). In vitro studies have identified distinct stages of oligodendrocyte progenitor cell maturation (Pfeiffer et al., 1993) from preprogenitors (Grinspan et al., 1990; Hardy and Reynolds, 1991) to motile progenitor cells (Raff et al., 1983), to nonmotile late progenitor cells (DuboisDalcq, 1987), and finally to postmitotic oligodendrocytes that form myelin internodes on contact with neuronal axons. The motile progenitors, first characterized from the rat optic nerve, generate either oligodendrocytes or a type of astrocyte under different

\footnotetext{
Received July 1, 1997; revised Aug. 29, 1997; accepted Sept. 16, 1997.

D.J.O. is a Senior Fellow of the National Multiple Sclerosis Society, D.M.O. was supported by grants from the National Institutes of Health (CA60673) and the Beckman Young Investigator program, and R.D.M. was supported by grants from the NMSS (RG2565) and the National Institutes of Health (NS31944 and MH54652). R.D.M. is a member of The Cancer Institute of New Jersey. We thank David Colman (Mt. Sinai, New York, NY) for anti-MBP antisera, Regina Armstrong (USUHS, Bethesda, MD) for A2B5 and O4 antibodies, Chris Edwards for construction of pMo.FGFRx.iresNeo, Noriko Kane-Goldsmith for excellent technical assistance, and the Center for Advanced Biotechnology and Medicine (Piscataway, NJ) for access to the Graphics Resource Center.

Correspondence should be addressed to Dr. Randall D. McKinnon, University of

Medicine and Dentistry of New Jersey, Robert Wood Johnson Medical School, 675

Hoes Lane, S-225, Piscataway, NJ 08854.

Dr. Osterhout's present address: Department of Cell Biology and Anatomy, Cornell Medical College, 1300 York Avenue, New York, NY 10021.

Copyright (c) 1997 Society for Neuroscience $0270-6474 / 97 / 179122-11 \$ 05.00 / 0$
}

culture conditions and are termed O-2A (oligodendrocyte-type-2 astrocyte) progenitor cells (Raff et al., 1983).

A number of polypeptide growth factors have been identified that affect oligodendrocyte progenitor cell development in vitro, including factors that affect progenitor cell proliferation (Noble et al., 1988; Raff et al., 1988; Bogler et al., 1990; McKinnon et al., 1990; Barres et al., 1994a; Canoll et al., 1996), migration (Armstrong et al., 1990; Milner et al., 1997), survival (Barres et al., 1993; Mayer et al., 1994; Gard et al., 1995; Yasuda et al., 1995), and differentiation (McMorris et al., 1986; McMorris and Dubois-Dalcq, 1988; McKinnon et al., 1993b; Barres et al., 1994b; Noll and Miller, 1994) and the synthesis of myelin (McMorris and Dubois-Dalcq, 1988). The most extensively characterized of these, platelet-derived growth factor (PDGF), promotes cell survival (Barres et al., 1992) and limited cell division (Noble et al., 1988; Raff et al., 1988) and induces a phenotype characterized by a bipolar morphology (Gard and Pfeiffer, 1993; McKinnon et al., 1993a) that is specifically associated with cell migration (Small et al., 1987). To date, PDGF is the only cytokine known to be chemotactic for oligodendrocyte progenitor cells in vitro (Armstrong et al., 1990). The fibroblast growth factors FGF-1 and FGF-2 are also mitogenic for oligodendrocyte progenitors (Besnard et al., 1989; McKinnon et al., 1990). In contrast to PDGF, FGF-2 promotes unlimited division and prevents oligodendrocyte progenitors from entering terminal differentiation (McKinnon et al., 1990). FGF also induces the expression of PDGF $\alpha$-receptors (PDGFR $\alpha$ ) on oligodendrocyte progenitor cells, increasing their sensitivity to PDGF (McKinnon et al., 1990). Thus, although FGF is not chemotactic (Armstrong et al., 1990), it primes oligodendrocyte progenitors to respond to PDGF and thereby contributes to their ability to adopt the migratory phenotype (McKinnon et al., 1993a). 
FGF stimulates the proliferation of progenitor cells in vitro in both neural and non-neural systems (for review, see Baird, 1994). FGF-1 and FGF-2 are expressed in both developing and adult brain (Ernfors et al., 1990; Gonzalez et al., 1990; Kalcheim and Neufeld, 1990; Schnurch and Risau, 1991), and FGF-1 is associated with enhanced myelination after a demyelinating lesion (Tourbah et al., 1992). Although these studies are consistent with a role for FGF in CNS myelination, this has yet to be demonstrated in vivo. To date, a genetic approach to study the role of FGF in oligodendrocyte development in vivo has not been informative, because targeted disruption of the murine FGF receptor gene $f g f r 1$ results in aborted development before or during gastrulation (Deng et al., 1994; Yamaguchi et al., 1994) and precludes an examination of the consequences of null mutations on later-emerging tissues.

We have taken an alternative approach to examine the role of FGF signaling in CNS myelination in vivo. Isolated progenitor cells were rendered nonresponsive to FGF in vitro using a dominant-negative FGF receptor 1 (FGFR1) transgene; then their development was examined after transplantation into neonatal rodent brain. We demonstrate that oligodendrocyte progenitors with impaired FGF signaling are unable to migrate into parenchyma and persist within the ventricles of recipient brain. These studies thus indicate that oligodendrocyte progenitor cells require FGF signaling to acquire their migratory phenotype in vivo and demonstrate the utility of a somatic cell mutagenesis approach for the study of gene function during CNS development.

\section{MATERIALS AND METHODS}

Recombinant DNA. The construct pMo.FGFRx.iresNeo (pMoFRx) used in this study (Fig. 1 $A$ ) contains a cDNA copy of the murine FGF (mFGF) receptor-1 (Ornitz and Leder, 1992; Benvenisty and Ornitz, 1995) and the neo resistance $\left(\mathrm{G} 418^{R}\right)$ gene (Southern and Berg, 1982), under transcriptional regulation of the Moloney MuLv retroviral long terminal repeat (Mo-LTR) promoter. The cDNA insert FGFRx encodes the three Ig domain forms of FGFR1 (splice form c), generating a protein that binds both FGF-1 and FGF-2 (Ornitz and Leder, 1992; Ornitz et al., 1996). A stop codon was placed at amino acid position 418 by $X b a \mathrm{I}$ linker insertion mutagenesis (Benvenisty and Ornitz, 1995). The encoded protein product contains extracellular and transmembrane domains of FGFR1 but lacks a cytoplasmic (catalytic protein tyrosine kinase) domain. This construct produces a bicistronic transcript with mFGFR1 and neo separated by an internal ribosome entry sequence (IRES) derived from the $5^{\prime}$ noncoding region of the encephalomyocarditis viral genome (Ghattas et al., 1991). Because neo lies downstream (3') from FGFRx, G418 resistant cells should express both transgenes. Control constructs used in this study include expression vectors encoding a cDNA version of the PDGFR $\alpha$ (Matsui et al., 1989) and a hybrid colony stimulating factor 1 (CSF1)/PDGFR $\alpha$ ( $f m s /$ PDGFR $\alpha$ ) construct (Yu et al., 1994).

Primary cell culture. Primary glial cultures were established from 2-d-old Sprague Dawley rats (Taconic Farms, Germantown, NY), and A2B5-immunoreactive oligodendrocyte progenitor cells were isolated from these cultures by immunoselection as described previously (McKinnon et al., 1990). Purified cells were plated on Falcon culture dishes (Becton Dickinson, Rutherford, NJ) or glass coverslips (Bellco Glass, Vineland, NJ) that had been precoated by incubating with a solution of $100 \mu \mathrm{g} / \mathrm{ml}$ poly-L-ornithine (Sigma, St. Louis, MO) in $15 \mathrm{~mm}$

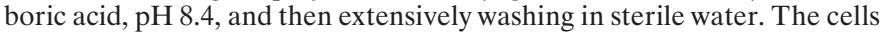
were cultured in DMEM containing $4.5 \mathrm{~g} / 1 \mathrm{D}$-glucose $(\mathrm{GIBCO} / \mathrm{BRL}$, Gaithersburg, MD), penicillin $(50 \mathrm{U} / \mathrm{ml})$, streptomycin and transferrin (each $50 \mu \mathrm{g} / \mathrm{ml}$ ), sodium selenite and triiodothyronine (each $30 \mathrm{nM}$ ), 50 $\mathrm{ng} / \mathrm{ml}$ bovine insulin, and $0.5 \%$ fetal bovine serum (FBS) (GIBCO/ BRL). The cells were expanded as secondary cultures (McKinnon and Zazanis, 1996) by supplementing with B104 neuroblastoma-conditioned medium (B104-cm; 20\% v/v) (Schubert et al., 1974; Louis et al., 1992). The cells were subcultured as described for the oligodendrocyte line CG-4 (Louis et al., 1992) using ATV trypsin solution (Irvine Scientific, Irvine, CA) to dislodge the cells from the culture flasks. All transfections, in vitro characterizations, and transplantations were done with these secondary oligodendrocyte progenitor cultures maintained in vitro for $<15$ passages (at a 1:3 split ratio).

DNA-mediated gene transfer. DNA transfections were performed using the calcium technique (Graham and Van der Eb, 1973) with cells plated at a density of $2 \times 10^{5}$ per $60 \mathrm{~mm}$ dishes in medium containing $10 \%$ FBS for $72 \mathrm{hr}$ as described previously (McKinnon and Zazanis, 1996). DNA precipitates were prepared by combining $1 \mu \mathrm{g}$ of plasmid DNA purified by $\mathrm{CsCl}$ density gradient centrifugation with $14 \mu \mathrm{g}$ of high molecular weight rat genomic DNA in $10 \mathrm{~mm}$ Tris, $\mathrm{pH} 7.5$, and $1 \mathrm{~mm}$ EDTA, followed by the addition of $0.1 \times$ volume of $2.5 \mathrm{M} \mathrm{CaCl}_{2}$. This was added dropwise to an equal volume of $2 \times$ HEPES-buffered saline, $\mathrm{pH} 7.05$, with mixing, generating a $\mathrm{CaPO}_{4}-\mathrm{DNA}$ coprecipitate that was added directly to the culture medium. The cultures were refed after $72 \mathrm{hr}$ and every $4 \mathrm{~d}$ thereafter with defined medium containing $20 \%$ B104-cm plus $400 \mu \mathrm{g} / \mathrm{ml}$ geneticin (G418; Sigma). B104-cm was replenished every 48 hr. Colonies were routinely visible after $10 \mathrm{~d}$ of culture, and individual colonies were isolated in cloning cylinders (Bellco Glass) and expanded as subclones in medium containing $200 \mu \mathrm{g} / \mathrm{ml} \mathrm{G} 418$.

In vitro analysis. Mitogen-stimulated cell proliferation assays were performed in 96 well Falcon plates in culture medium supplemented with recombinant human PDGF-AA or FGF-2 (R \& D Systems, Minneapolis, $\mathrm{MN}$ ). Cells were plated at 2000 cells/well, incubated for $24 \mathrm{hr}$ in culture medium (described above) without mitogens, and then exposed to the indicated concentrations of recombinant growth factors for $20 \mathrm{hr}$ with 0.1 $\mu \mathrm{Ci}$ of $\left[{ }^{3} \mathrm{H}\right]$ thymidine (specific activity, $48 \mathrm{Ci} / \mathrm{mmol}$; Amersham, Arlington Heights, IL) present for the final $4 \mathrm{hr}$. The cells were harvested onto Whatman GF/C filter paper using an automated cell harvester (Brandel, Gaithersburg, MD), and incorporated radioactivity was determined by liquid scintillation counting. All data points were performed in triplicate wells, results represent the mean $\pm \mathrm{SD}$ in cpm, and all experiments were performed at least three times. Cell migration assays were performed with cells plated on $12 \mathrm{~mm}$ glass coverslips that were transferred into 35 $\mathrm{mm}$ culture dishes and cultured in medium supplemented with FGF-2 (5 $\mathrm{ng} / \mathrm{ml})$ plus PDGF-AA (10 ng/ml). For qualitative analysis, cells were photographed after $24-72 \mathrm{hr}$; for quantitative analysis, the migration of individual cells was monitored for $16 \mathrm{hr}$ by time lapse photography using a Polaroid MicroCam mounted on a Zeiss Axiovert 100 TV with a $40 \times$ LD Acroplan objective.

Cell transplantation. Transfected cells expressing recombinant constructs encoding neomycin phosphotransferase II (NPTII; G418 ${ }^{\mathrm{R}}$ ) were maintained in medium lacking G418 for one passage before transplantation. All cells were labeled in vitro with fluorescent cell markers [either PKH2 (fluorescein) or PKH26 (rhodamine) optics; Sigma] according to the manufacturer's directions, then resuspended in PBS (10 mM sodium phosphate, $150 \mathrm{~mm} \mathrm{NaCl}, \mathrm{pH}$ 7.2), and transplanted into the right thalamus of neonatal rat recipients at postnatal day 2 (P2) or day 6 (P6). The animals were anesthetized with halothane (Halocarbon Labs, River Edge, NJ) before transplant. A Hamilton $701 \mu \mathrm{l}$ syringe was used to slowly inject $1 \mu \mathrm{l}(5,000$ or 20,000 cells in individual experiments) into the brain $1 \mathrm{~mm}$ rostral from bregma and $1 \mathrm{~mm}$ right of midline, to a depth of $3 \mathrm{~mm}$ (P2 rat) or $5 \mathrm{~mm}$ (P6 rat). The animals were returned to their mothers after the procedure. At the indicated times after transplantation, the animals were anesthetized with sodium pentobarbital $(40 \mathrm{mg} / \mathrm{kg}$, i.p.; Abbot Labs, Irving, TX) and perfused with $1 \mathrm{U} / \mathrm{ml}$ heparin (Elkins-Sinn, Cherry Hill, NJ) in saline, followed by $4 \%$ paraformaldehyde in phosphate buffer, $\mathrm{pH}$ 7.4. The brains were removed, post-fixed in $4 \%$ paraformaldehyde overnight, equilibrated in $10 \%$ followed by $20 \%$ sucrose in PBS, frozen in OCT compound (TissueTek; Baxter Scientific, Boston, MA), and serially sectioned (20 $\mu \mathrm{m}$ sections) on a Jung Frigocut cryostat. Transplanted cells were visualized in the sections using a Zeiss Axiovert 100 TV fluorescent microscope with either $40 \times$ Achrostigmat or $100 \times$ Plan-Neofluar objectives, either under PKH2 or PKH26 optics.

Immunohistochemistry. Cells growing on $12 \mathrm{~mm}$ glass coverslips (Bellco Glass) were washed in PBS, fixed for 5 min in $2 \%$ paraformaldehyde, and then exposed to antibody solutions for $30 \mathrm{~min}$ at room temperature in a humid chamber as described previously (McKinnon et al., 1990). Primary antibody dilutions in PBS were: monoclonals A2B5, $\mathrm{O} 1$, and $\mathrm{O} 4,1: 10$ dilution of tissue culture supernatants; anti-myelin basic protein (MBP) serum, 1:500 dilution; and anti-GFAP, anti-5-bromo-2'deoxyuridine (BrdU; Chemicon, Temecula, CA), and anti-human CSF1receptor (Oncogene Research Products, Cambridge, MA), as recommended by the manufacturer. Fluorescent-conjugated secondary antibodies (Pierce, Rockford, IL) were used at $25 \mu \mathrm{g} / \mathrm{ml}$. For MBP immunoreactivity, the coverslips were first treated with Bouin's fixative 
(5 min) and then $10 \%$ normal goat serum (10 $\mathrm{min})$ before incubating with antisera (60 $\mathrm{min})$, and immunoreactivity was detected by incubating with biotinylated anti-rabbit antibody for $30 \mathrm{~min}$, washing in $0.1 \mathrm{M} \mathrm{NaHCO}_{3}$ and $0.15 \mathrm{M} \mathrm{NaCl}, \mathrm{pH} 8.4$, and then incubating with fluorescein avidin (10 $\mu \mathrm{g} / \mathrm{ml} ; 30 \mathrm{~min}$; Vector Laboratories, Burlingame, CA). The coverslips were mounted on glass slides with Fluoromount-G (Southern Biotechnology, Birmingham, AL) and then viewed and photographed with Kodak TMAX 400 ASA print or Elite II 100 color slide film.

NPTII protein was detected in cultured cells in vitro, and in transplanted cells in vivo, using biotinylated anti-NPTII (5 Prime-3 Prime, Inc., Boulder, $\mathrm{CO})$. Cultured cells were fixed in acid:alcohol (5:95) at $-20^{\circ} \mathrm{C}$ for $5 \mathrm{~min}$, followed by incubation with anti-NPTII antibody (1:100 in PBS) for $2 \mathrm{hr}$ at room temperature (RT). Cryostat sections of paraformaldehyde-fixed tissue samples (grafted brain) were permeabilized with $0.5 \%$ Triton X-100 in PBS for 5 min and then incubated first with $10 \%$ normal goat serum for $30 \mathrm{~min}$ at RT followed by anti-NPTII antibody (1:100 in PBS) overnight at $4^{\circ} \mathrm{C}$. The sections were rinsed and incubated in $\mathrm{ABC}$ reagent according to the manufacturer's instructions (Vectastain Elite kit; Vector Laboratories), and NPTII immunoreactivity was detected with the DAB substrate kit (Vector Laboratories). For cells in culture, immunoreactive cells were detected with either Vectastain Elite or biotinylated-fluorescein conjugate (Vector Laboratories).

The proliferation of grafted cells was determined by immunohistochemical analysis of BrdU (Sigma) incorporation (Nowakowski et al., 1989). Transplant recipients received six intraperitoneal injections (each injection, $50 \mu \mathrm{g} / \mathrm{gm}$ ) over the course of $9 \mathrm{hr}$ and then were perfused as described above $30 \mathrm{~min}$ after the last injection. The brains were embedded in paraffin and serially sectioned ( $8 \mu \mathrm{m}$ sections). Before staining, the sections were deparaffinized and permeabilized using $0.1 \%$ trypsin followed by $2 \mathrm{~N} \mathrm{HCl}$ treatment, then incubated with anti-BrdU antibody (1:75 dilution; Chemicon), and visualized with the Vectastain Elite and DAB substrates (Vector Laboratories) according to the manufacturer's instructions.

Biochemical techniques. For Northern blot analysis, total RNA was isolated from cultured oligodendrocyte progenitor cells as described by Ansubel et al. (1988). Cells in monolayer culture were lysed in $4 \mathrm{M}$ guanidinium isothiocyanate, $5 \mathrm{~mm}$ sodium citrate, $\mathrm{pH} 7.0,0.1 \mathrm{~m} \beta$ mercaptoethanol, and $0.1 \%$ Sarkosyl; and total RNA was purified by $\mathrm{CsCl}$ gradient centrifugation, extracted in 4:1 chloroform/butanol, and precipitated in ethanol. The RNA precipitate was resuspended in RNasefree water and quantitated by spectrophotometry. Total RNA $(10 \mu \mathrm{g})$ was separated on a $1.5 \%$ agarose gel containing $2.2 \mathrm{M}$ formaldehyde, transferred overnight to a nylon membrane (Oncor, Gaithersburg, MD), and cross-linked under ultraviolet light using a Stratalinker (Stratagene, La Jolla, CA). Radiolabeled FGFR1 cDNA probes were prepared using random hexanucleotide primers (Prime-a-Gene; Promega, Madison, WI) with $\left[\alpha-{ }^{32} \mathrm{P}\right] \mathrm{dCTP}$ (specific activity, $3000 \mathrm{Ci} / \mathrm{mmole}$; Amersham). The blot was prehybridized for $2 \mathrm{hr}$ at $42^{\circ} \mathrm{C}$ in Hybrisol I (Oncor), hybridized with labeled probe for $14 \mathrm{hr}$ at $42^{\circ} \mathrm{C}$, washed at high stringency $(0.2 \times$ SSC, $0.2 \%$ SDS; $67^{\circ} \mathrm{C}$ ), and then exposed to Fuji RX film for autoradiography. FGF receptors on parental and O2A ${ }^{\mathrm{FRx}}$ mutant (clone b1) progenitor cells were identified by cross-linking ${ }^{125}$ I-FGF to live cells as described by Benvenisty and Ornitz (1995). FGF-binding proteins were resolved by SDS-PAGE and identified by autoradiography.

\section{RESULTS}

\section{Inactivation of FGF signaling in oligodendrocyte progenitors expressing a truncated FGFR1 transgene}

To disrupt FGF signaling in oligodendrocyte progenitor cells, we introduced a recombinant plasmid encoding a modified version of the wild-type murine FGFR1 (Fig. $1 A$ ) into cultured oligodendrocyte progenitors by DNA-mediated gene transfer (McKinnon and Zazanis, 1996). The cDNA insert of this construct contains a stop codon introduced at amino acid position 418 of the $f g f r l$ sequence and encodes a truncated form of the receptor (denoted FGFRx) that lacks the cytoplasmic signaling domain of the protein. When expressed in transfected cells, the truncated FGFRx receptor inhibits signal transduction by multiple types of endogenous wild-type FGFRs (Ueno et al., 1992; Benvenisty and Ornitz, 1995) in a dominant-negative manner (Herskowitz, 1987). This expression vector also encodes the NPTII gene (Fig. 1A),

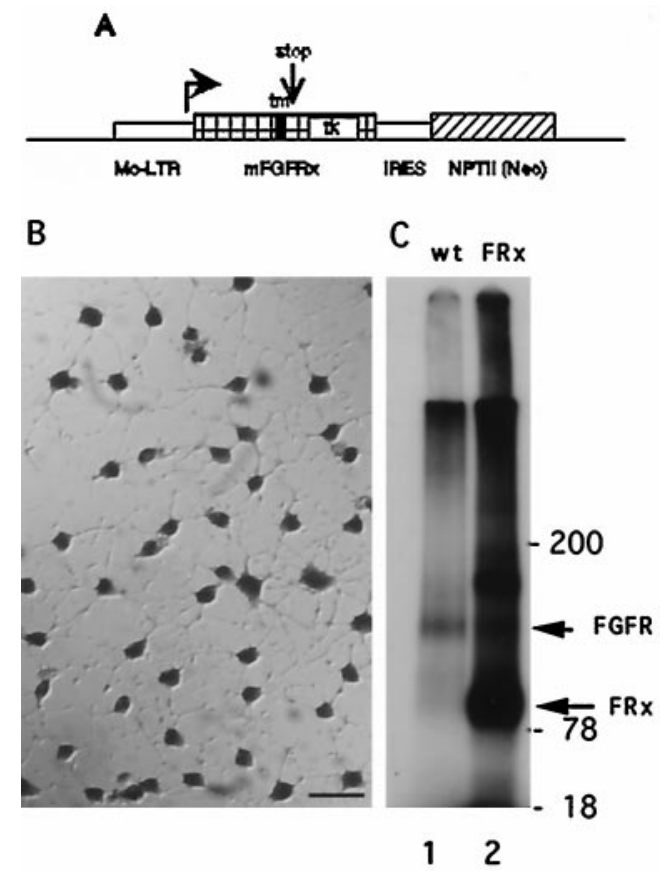

Figure 1. Expression of a dominant-negative FGF receptor transgene in oligodendrocyte progenitor cells. $A$, Schematic representation of transfection vector pMo.FGFRx.iresNeo ( $p M o F R x$ ), encoding (left to right) the Moloney LTR transcriptional regulatory sequence (Mo-LTR; arrow indicates polarity of transcription), a truncated form of the murine FGFR1 receptor $(m F G F R x)$, internal ribosome entry sequence (IRES), and the neomycin phosphotransferase (NPTII) gene. The vertical arrow indicates the location of a stop codon introduced in FGFR1 by $\mathrm{XbaI}$ linker mutagenesis (Benvenisty and Ornitz, 1995) and causing premature termination of translation 22 amino acids after the transmembrane domain $(\mathrm{tm})$ and upstream from the cytoplasmic tyrosine kinase $(t k)$ domain. $B$, Anti-NPTII immunoreactivity in oligodendrocyte progenitor cells transfected with pMoFRx. Transfected cells had prominent staining of the soma. Scale bar, $25 \mu \mathrm{m}$. $C,{ }^{125} \mathrm{I}$-FGF binding proteins present in extracts of nontransfected parental progenitor cells (lane 1;wt) and progenitors transfected with pMoFRx (lane 2; FRx). Sizes of electrophoretic markers are indicated in kilodaltons, and arrows indicate a prominent FGF-binding protein migrating at the expected size for wildtype FGFR in both lanes and a protein with the predicted size of FGFRx $(F R x ; 100 \mathrm{kDa})$ in transfected cells.

which confers resistance to the antibiotic geneticin (G418) and provides both a selectable (Southern and Berg, 1982) and immunohistochemically detectable marker for cells that express the transgene. Both transgenes are expressed on a bicistronic RNA transcript linked by the IRES, with NPTII encoded downstream of FGFRx such that cells expressing the NPTII protein must coexpress FGFRx.

Oligodendrocyte progenitor cells were isolated from mixed glial cultures established from neonatal rat cortex (McCarthy and de Vellis, 1980) as described previously (McKinnon et al., 1990) and amplified with B104-conditioned medium (Louis et al., 1992). The majority of these cells (50-75\%) are A2B5-immunoreactive under these conditions, and they progressively acquire immunoreactivity to oligodendrocyte differentiation markers $\mathrm{O} 4$ and MBP when cultured in the absence of mitogens (see below). These cells are mitogen dependent for cell division and are within the Hayflick limit (50 \pm 10 doublings) for senescence and thus satisfy the criteria for nonimmortalized cell strains in vitro (Hayflick, 1965). Cells were transfected with control constructs 
Table 1. Transfection of oligodendrocyte progenitor cells with pMo.FGFRx.iresNeo constructs

\begin{tabular}{lc} 
Vector & No. of colonies \\
\hline no DNA & 0 \\
PDGFR $\alpha$ & $>76$ \\
FGFR1 & 56 \\
FGFRx & 58
\end{tabular}

The frequency of G418 ${ }^{R}$ colonies obtained after transfection of oligodendrocyte progenitor cells with an expression vector (pMo.FGFR x.iresNeo, Fig. 1) encoding cDNA versions of human PDGFR $\alpha$, murine FGFR1, or a truncated (dominantnegative) version, FGFRx. Values represent the number of colonies $/ 2 \times 10^{5}$ transfected cells $/ 5 \mu \mathrm{g}$ of plasmid DNA.

including the wild-type FGFR1 receptor, $\operatorname{PDGFR} \alpha$, or $\mathrm{fms} /$ PDGFR $\alpha$ chimera or with the truncated FGFRx transgene and clonally selected in medium containing G418. The $\mathrm{fms} / \mathrm{PDGFR} \alpha$ chimera transgene encodes the ectodomain of human CSF1 receptor, which recognizes human but not rodent CSF1 and therefore would not be expected to respond to endogenous ligand when transfected cells are transplanted into the rodent CNS. Individual transformants from independent transfection experiments were isolated and expanded as independent cell strains $\left(\mathrm{O} 2 \mathrm{~A}^{\mathrm{FR} 1}, \mathrm{O} 2 \mathrm{~A}^{\mathrm{PR} \alpha}, \mathrm{O} 2 \mathrm{~A}^{\mathrm{fms}}\right.$, and $\mathrm{O} 2 \mathrm{~A}^{\mathrm{FRx}}$ cells, respectively). The frequency of G418 resistant colonies obtained with the FGFR $x$ construct was comparable with that obtained with control constructs (Table 1), indicating that the presence of transgenes encoding the truncated FGFRx did not impair the ability of oligodendrocyte progenitor cells to survive or proliferate under the culture conditions used in this study. Analysis of one clonal derivative ( $\mathrm{O} 2 \mathrm{~A}^{\mathrm{FRxb} 1}$ cells) demonstrated the presence of both fgfr.nptII transcripts (data not shown), and NPTII immunoreactivity (Fig. $1 B$ ), and cross-linking studies (Fig. $1 C$ ) revealed an FGF-binding protein of $M_{\mathrm{r}} 100 \mathrm{kDa}$, expected for the truncated FGFRx receptor, that was expressed at a level at least fivefold higher than that of wild-type receptors. Additional bands detected in this analysis (Fig. 1C, lane 2) may represent multimeric forms of FGF-binding proteins.

To characterize the transfectants further, we compared the phenotypes of untransfected "parental" and O2A ${ }^{\mathrm{FRx}}$ progenitor cells under different culture conditions in vitro. When maintained in the presence of B104-conditioned medium, both parental (data not shown) and $\mathrm{O} 2 \mathrm{~A}^{\mathrm{FRx}}$ (Fig. $1 B$ ) cells were multipolar with thin branched processes and were immunopositive with antibodies A2B5 (50.5 and 74.1\%) and O4 (17.9 and 15.5\%, respectively) and negative for the mature oligodendrocyte differentiation marker MBP. In the absence of mitogens, both parental and $\mathrm{O} 2 \mathrm{~A}^{\mathrm{FRx}}$ cells underwent morphological differentiation with an enlargement of the cell body, enhanced branching of processes, an increase in $\mathrm{O} 4$ immunoreactivity $(>90 \%)$, and the induction of MBP expression ( $>80 \% \mathrm{MBP}+)$. Thus, the expression of the FGFR $x$ transgene did not seem to alter the differentiation state of $\mathrm{O} 2 \mathrm{~A}^{\mathrm{FRx}}$ progenitor cells relative to that of parental control cells under these culture conditions.

The ability of both parental and $\mathrm{O} 2 \mathrm{~A}^{\mathrm{FRx}}$ cells to respond to mitogens was examined by measuring mitogen-stimulated DNA synthesis in vitro (Fig. 2). Cells were cultured in defined medium in the presence of increasing concentrations of mitogen, and the stimulation of DNA synthesis was measured after $20 \mathrm{hr}$ by monitoring the incorporation of $\left[{ }^{3} \mathrm{H}\right]$ thymidine. Both parental and $\mathrm{O} 2 \mathrm{~A}^{\mathrm{FRx}}$ oligodendrocyte progenitor cells showed a dose-

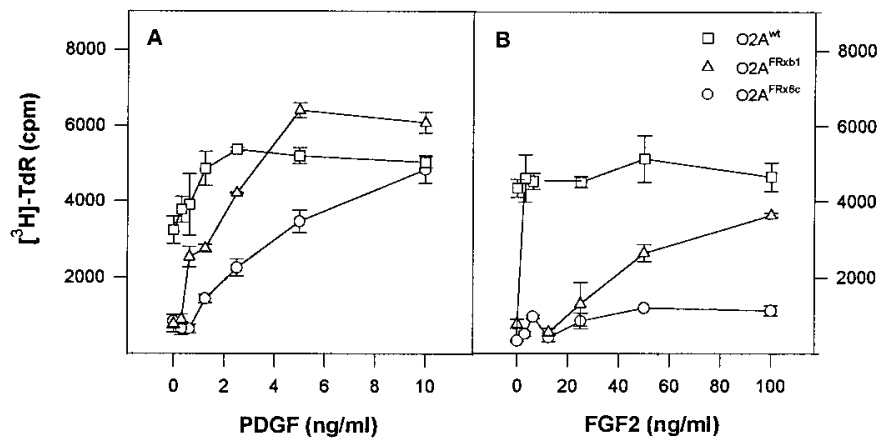

Figure 2. Impaired FGF signaling in oligodendrocyte progenitor cells expressing the truncated mFGFR x receptor. $A, B,\left[{ }^{3} \mathrm{H}\right]$ Thymidine incorporation in nontransfected parental oligodendrocyte progenitor cells (squares) and two independently isolated, clonally derived strains transfected with pMoFRx (triangles, circles). Cells were cultured for $20 \mathrm{hr}$ in the presence of the indicated concentrations of PDGF-AA $(A)$ or FGF-2 $(B)$, and results represent the mean $\pm \mathrm{SD}$ of triplicate samples and are representative of a minimum of three independent assays. All cell strains responded to physiological levels of PDGF $(5 \mathrm{ng} / \mathrm{ml})$, although transfected cells were nonresponsive at physiological levels of FGF-2 $(2-5 \mathrm{ng} / \mathrm{ml})$.

dependent increase in $\left[{ }^{3} \mathrm{H}\right]$ thymidine incorporation in response to PDGF-AA (Fig. $2 A$ ). Parental O-2A progenitor cells responded maximally with $<5 \mathrm{ng} / \mathrm{ml}$ PDGF, whereas two independently derived $\mathrm{O} 2 \mathrm{~A}^{\mathrm{FRx}}$ lines required somewhat higher (5-10 $\mathrm{ng} / \mathrm{ml}$ ) PDGF concentrations for maximal response. Wild-type oligodendrocyte progenitors also responded to FGF-2 (Fig. 2B), with maximal response at $1-2 \mathrm{ng} / \mathrm{ml}$. In contrast, $\mathrm{O} 2 \mathrm{~A}^{\mathrm{FRx}}$ cells failed to respond to FGF-2 at concentrations ranging from 1 to 25 $\mathrm{ng} / \mathrm{ml}$ (Fig. $2 B)$. One clonal derivative $\left(\mathrm{O} 2 \mathrm{~A}^{\mathrm{FR} \times \mathrm{x} 1}\right.$ cells) responded weakly to FGF-2 at much higher $(>50 \mathrm{ng} / \mathrm{ml})$ concentrations, whereas a second subclone $\left(\mathrm{O} 2 \mathrm{~A}^{\mathrm{FRx} 6 \mathrm{c}}\right)$ was nonresponsive even at this higher dose. This pattern of growth factorinduced thymidine incorporation was observed in four independently isolated $\mathrm{O} 2 \mathrm{~A}^{\mathrm{FRx}}$ clones tested, suggesting that impaired FGF signaling was not caused by random clonal variation and that the truncated FGFRx transgene acts in a dominantnegative manner to interrupt FGF signaling in these cells. These observations also imply that FGF signaling is not essential for the proliferation of oligodendrocyte progenitor cells under the culture conditions used (in the presence of B104-conditioned medium).

\section{Impaired migration of oligodendrocyte progenitors expressing a truncated FGFR1 transgene in vitro}

FGF maintains oligodendrocyte progenitors at the O4immunoreactive progenitor cell stage (Pfeiffer et al., 1993) and increases PDGFR $\alpha$ expression levels (McKinnon et al., 1990), thereby modulating the ability of progenitor cells to respond to PDGF (McKinnon et al., 1993a). Consequently, in addition to its inhibition of FGF signaling, overexpression of the dominantnegative FGFRx transgene would be predicted to alter the response of these cells to PDGF. In two subclones examined, $\mathrm{O} 2 \mathrm{~A}^{\mathrm{FRx}}$ cells showed a slight decrease in response to mitogenic stimulation by PDGF relative to control cells (Fig. $2 A$ ), suggesting a modulating effect of the FGFRx transgene on PDGFR $\alpha$ signaling. Because PDGF can stimulate cell migration (Armstrong et al., 1990; Milner et al., 1997) as well as proliferation, we also compared the ability of parental and $\mathrm{O} 2 \mathrm{~A}^{\mathrm{FRx}}$ cells to migrate in vitro (Fig. 3). Cells plated on coverslips were cultured in the 

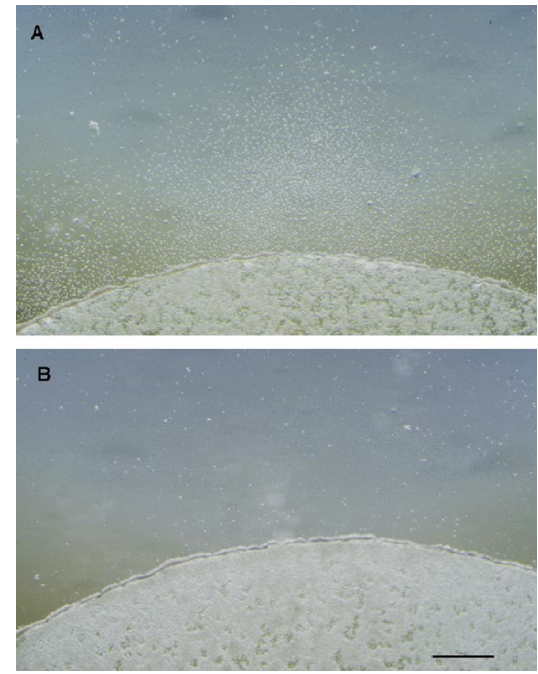

Figure 3. Impaired migration of oligodendrocyte progenitor cells expressing the truncated mFGFRx receptor. Photomicrographs of parental oligodendrocyte progenitor cells (top) and progenitor cells transfected with pMoFRx (bottom) that were cultured for $72 \mathrm{hr}$ in the presence of PDGF plus FGF-2 are shown. Parental progenitor cells showed extensive radial migration, whereas FGFRx cells did not. Short-term time lapse cinematography also indicated that transfected cells did not migrate (see Results). Scale bar, $650 \mu \mathrm{m}$.

presence of FGF plus PDGF, conditions under which parental cells revert from stellate progenitors to bipolar, migratory progenitors (McKinnon et al., 1993a). Under these conditions, pa- rental cells migrated in a radial array from the coverslip onto the culture dish surface (Fig. 3, top). O2 $\mathrm{A}^{\mathrm{FRx}}$ cells, in contrast, did not migrate away from the coverslip (Fig. 3, bottom). When monitored by time lapse cinematography, $\mathrm{O} 2 \mathrm{~A}^{\mathrm{FRx}}$ cells were also nonmotile compared with control cells over a $16 \mathrm{hr}$ time period (data not shown). The lack of migration of $\mathrm{O} 2 \mathrm{~A}^{\mathrm{FRx}}$ cells was unlikely to be a result of the clonal selection process that generated these cells, because O-2A progenitor cells transfected with the chimeric $f m s / \mathrm{PDGFR} \alpha$ construct (Yu et al., 1994) migrated in response both to PDGF and to recombinant human CSF1 (via the transgene receptor) under similar conditions in vitro (S. Ebner, unpublished observations). Because the migration of O-2A progenitors in vitro is stimulated by PDGF (Armstrong et al., 1990), these results further suggest that expression of the FGFRx transgene modulated the ability of transfected cells to respond to PDGF in vitro.

\section{Impaired migration of oligodendrocyte progenitors expressing a truncated FGFR1 transgene in vivo}

The behavior of $\mathrm{O} 2 \mathrm{~A}^{\mathrm{FRx}}$ progenitor cells in vivo was examined by transplanting into neonatal rat brain and examining their distribution at various times after transplantation. The fate of $\mathrm{O} 2 \mathrm{~A}^{\mathrm{FRx}}$ cells (Figs. $4 A, 5$ ) was compared with that of wild-type (parental) oligodendrocyte progenitors (Fig. $4 B$ ) and with that of progenitors transfected with control cDNA constructs encoding wild-type versions of FGFR1, PDGFR $\alpha$, and a $f m s / \operatorname{PDGFR} \alpha$ chimera (see Fig. 6) that is inactive in rodent brain. All cells were first labeled in vitro with fluorescent markers, either $\mathrm{PKH} 2$ or $\mathrm{PKH} 26$, and then injected into the telencephalon (thalamus) of postnatal day
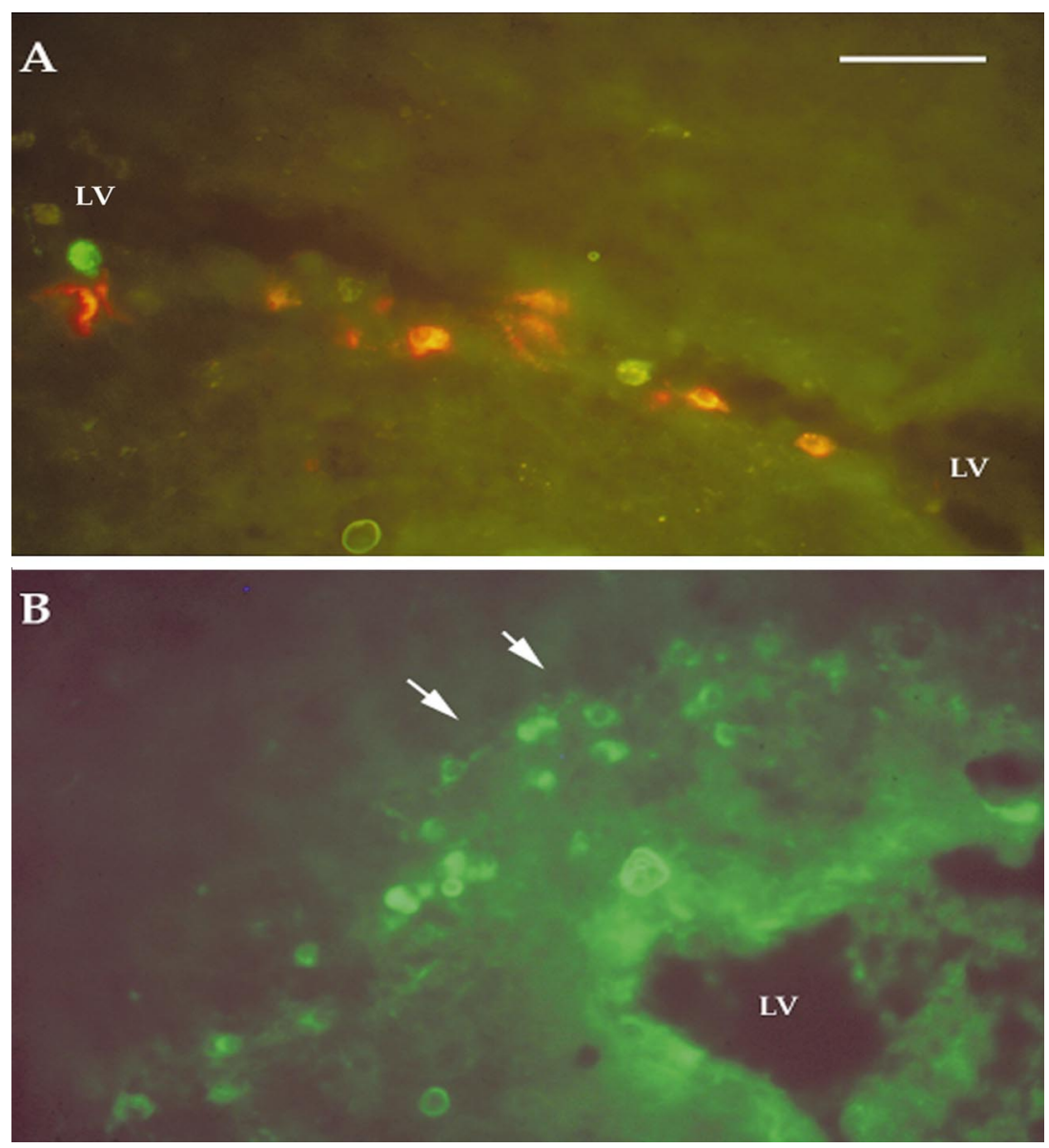

Figure 4. Cotransplantation of fluorescent-labeled oligodendrocyte progenitor cells. Horizontal sections of postnatal day 4 rat brain (rostral, top) $48 \mathrm{hr}$ after transplantation with parental progenitors (PKH2 label, green fluorescence) plus pMoFRx-transfected progenitors (PKH26 label, red fluorescence). $A$, Retention of distinct fluorescent markers by cotransplanted wild-type and mutant cells. Transplanted cells located within the lateral ventricle $(L V)$ specifically retained cell surface-associated PKH2 or PKH26 fluorescent markers. $B$, Migration of parental oligodendrocyte progenitor cells in host CNS. PKH2-labeled (wild-type) progenitor cells were found distal to the site of injection, entering the corpus callosum rostral to the $L V$. The fluorescence label was predominantly in the cell soma, whereas processes extended in situ in the presumed leading edge of migration (arrows) were less intensely labeled. Scale bar, $35 \mu \mathrm{m}$. 

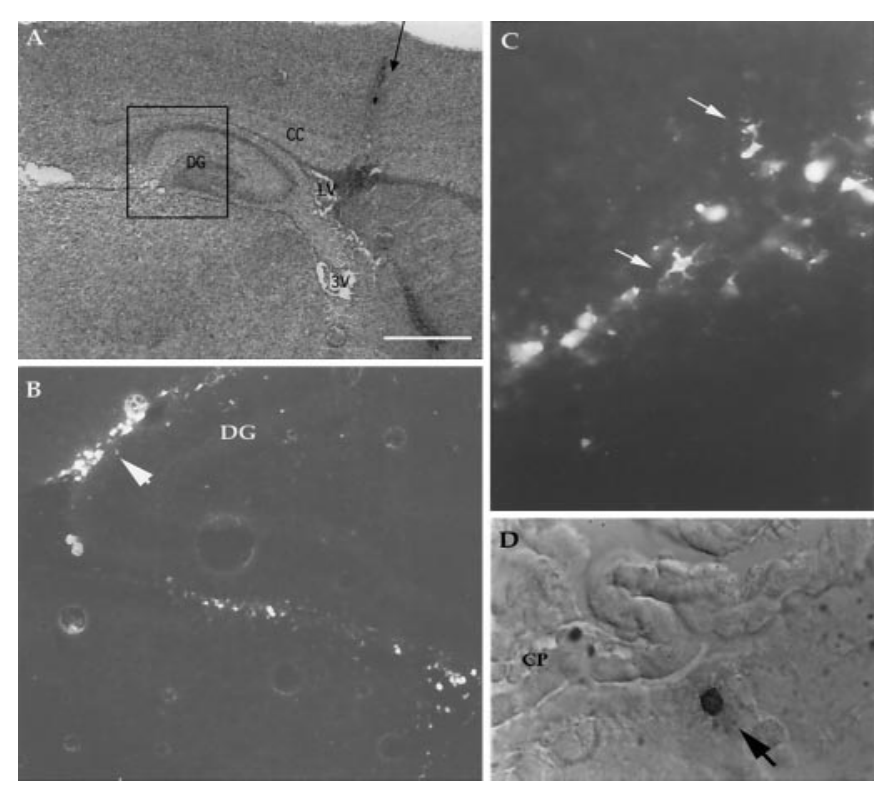

Figure 5. Transplanted FGFRx progenitor cells fail to migrate into brain parenchyma. Sagittal sections of transplant recipient rat brains $72 \mathrm{hr}$ $(A-C)$ and $7 \mathrm{~d}$ after transplantation $(D)$; dorsal is to the top and anterior is to the right for all micrographs. $A$, Phase micrograph showing the needle track through the cortex in the upper right (arrow depicts injection path). $C C$, Corpus callosum; $L V$, lateral ventricle; $3 V$, third ventricle; and $D G$, dentate gyrus. $B$, Rhodamine fluorescence of PKH26-labeled FGFRxexpressing cells surrounding the dentate gyrus, delineated by boxed region in $A$. $C$, Region denoted by the arrow in $B$, showing FGFRx cells lining the hippocampal fissure and extending processes through the ependymal layer (arrows). D, Anti-NPTII immunoreactivity in FGFRx-expressing cells. Mutant cells found adjacent to the ependymal layer and the lateral ventricle continued to express the bicistronic NPTII transgene in vivo. $C P$, Choroid plexus. Scale bars: $A, 650 \mu \mathrm{m} ; B, 120 \mu \mathrm{m} ; C, 30 \mu \mathrm{m} ; D, 25 \mu \mathrm{m}$.

2 recipient rats. The fluorescent cell markers were retained in the plasma membranes of labeled cells both in vitro and in vivo throughout the time points examined in this study (7 d) and had no demonstrable effects on the viability of labeled cells in vitro. The labeling became somewhat punctate at longer time points, with processes extended in situ having less label than the cell soma. The injection path was identifiable $24 \mathrm{hr}$ after transplantation by a needle track penetrating the tissue (see Fig. $5 A$ ). The transplantation produced a gliotic reaction around this track, detected after $72 \mathrm{hr}$ by immunoreactivity of glial fibrillary acidic protein (data not shown). When visualized under fluorescence after $24 \mathrm{hr}$, transplanted cells were found along this needle tract and within a small cyst at the site of transplant. This distribution of grafted cells was typical of all cells examined at $24 \mathrm{hr}$ after transplantation in this study.

The behavior of parental and $\mathrm{O} 2 \mathrm{~A}^{\mathrm{FRx}}$ progenitor cells was directly compared by cotransplanting both cell types into the same host (Fig. 4A), after mixing cells labeled in vitro with the distinct fluorescence markers PKH2 (parental) and PKH26 $\left(\mathrm{O} 2 \mathrm{~A}^{\mathrm{FRx}}\right)$. At $48 \mathrm{hr}$ after transplantation, many PKH2-labeled parental cells had moved from the site of injection and were observed both within the lateral ventricle (Fig. 4A) and within axonal tracts including the corpus callosum (Fig. 4B). In contrast, PKH26-labeled $\mathrm{O} 2 \mathrm{~A}^{\mathrm{FRx}}$ cells remained either at the site of injection or within the neighboring ventricles (Fig. 4A). A similar distribution was seen at $7 \mathrm{~d}$ after transplantation. The fluorescent cell markers specifically reported the location of individual grafted cells, and not phagocytic cells, because the fluorescent
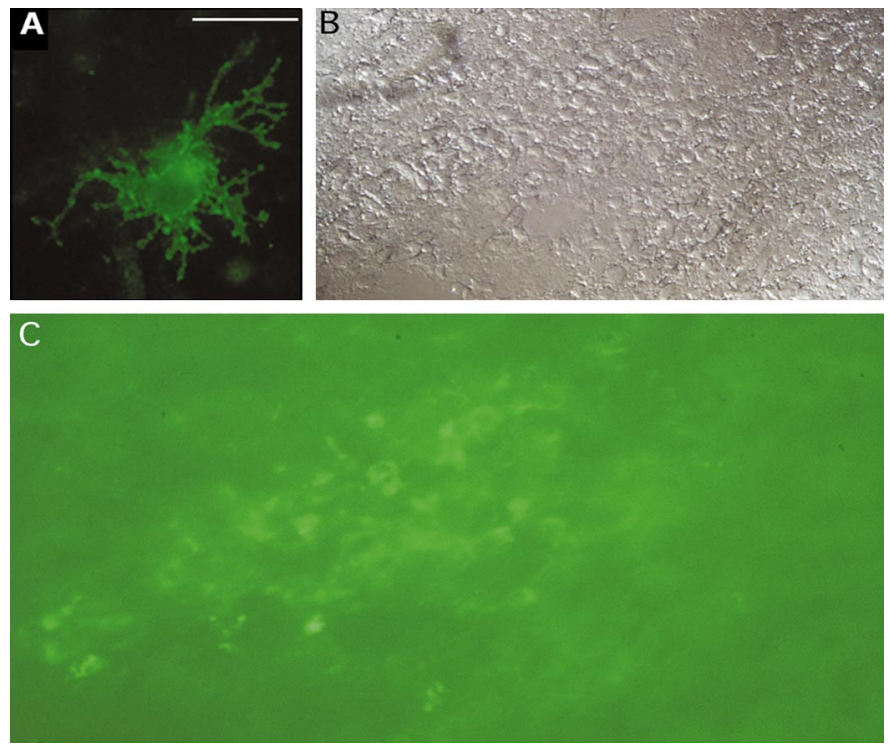

Figure 6. Migration of control-transfected oligodendrocyte progenitor cells in vivo. Oligodendrocyte progenitor cells transfected with a nonsignaling (hCSFR1) receptor transgene migrate in rat brain. $A$, Anti-CSFR1 immunoreactivity of transfected $\mathrm{O} 2 \mathrm{~A}^{\mathrm{fms}}$ progenitor cells in vitro. $B, C$, Horizontal sections of recipient brain $7 \mathrm{~d}$ after transplantation. Caudal is top; the same field is depicted in phase contrast $(B)$ and fluorescence $(C)$, showing PKH2-labeled O2A ${ }^{\mathrm{fms}}$ cells that have migrated into parenchyma. Scale bar: $A, 35 \mu \mathrm{m} ; B, 30 \mu \mathrm{m} ; C, 15 \mu \mathrm{m}$.

dyes were cell surface associated and mutually exclusive (Fig. $4 A$ ). Because control cells migrated under these conditions, the lack of migration of $\mathrm{O} 2 \mathrm{~A}^{\mathrm{FRx}}$ cells was not attributable to some aspect of the transplantation procedure. The cotransplantation studies thus demonstrated a specific lack of migration of $\mathrm{O} 2 \mathrm{~A}^{\mathrm{FRx}}$ cells into brain after transplantation.

The distribution of transplanted $\mathrm{O} 2 \mathrm{~A}^{\mathrm{FRx}}$ mutant cells in vivo was distinct from that of control transplants, including both nontransfected parental cells and progenitor cells transfected with control cDNA constructs. At all time points examined, $\mathrm{O} 2 \mathrm{~A}^{\mathrm{FRx}}$ cells were located primarily along the surface of the ventricles (Fig. 5B,C) and adjacent to the choroid plexus (Fig. 5D) and were rarely found within the host brain parenchyma. This distribution pattern was visible as early as $48 \mathrm{hr}$ after transplantation, did not change over the time points examined (up to $7 \mathrm{~d}$ ), and was observed with two independently isolated $\mathrm{O} 2 \mathrm{~A}^{\mathrm{FRx}}$ clonal lines. At $72 \mathrm{hr}$ after transplantation, the morphology of $\mathrm{O} 2 \mathrm{~A}^{\mathrm{FRx}}$ cells resembled that of the parental transfected cells, extending short processes and interacting with adjacent cells in the choroid plexus and ependymal layer of the ventricles (Fig. $5 C, D$ ). The inability to migrate was specifically associated with the dominant-negative FGFRx transgene (see below), suggesting that impaired FGF signaling may be responsible for their failure to migrate in vivo.

\section{Migration of control oligodendrocyte progenitor cells in vivo}

In contrast to $\mathrm{O} 2 \mathrm{~A}^{\mathrm{FRx}}$ cells, the distribution of PKH2-labeled parental cells changed significantly after transplantation (Fig. $4 B$ ). After $48 \mathrm{hr}, \mathrm{O} 2 \mathrm{~A}^{\mathrm{wt}}$ cells were dispersed in brain parenchyma, and after $72 \mathrm{hr}$, grafted cells could be found within axonal fiber tracts including the corpus callosum (Fig. 4B), internal capsule, and hippocampal fimbria. Parental cells were also observed along the needle tract and at the site of injection, although 
the number of these cells declined over time (see below). A similar distribution of control transfected cells was observed with transplants of $\mathrm{O} 2 \mathrm{~A}^{\mathrm{fms}}$ (Fig. 6), O2A $\mathrm{A}^{\mathrm{PR} \alpha}$ (Fig. 7), and O2A $\mathrm{A}^{\mathrm{FR} 1}$ (data not shown) cells. The majority of cells that had moved away from the injection site extended several processes within host brain parenchyma (Figs. $4 B, 6 C$ ). The age of the host at the time of transplantation (postnatal day 2 or 6 ) had no apparent effect on the distribution of grafted cells within the brain. Because the expression of other transgenes had no apparent effect on the dispersion and distribution of transplanted cells in the brain, the lack of migration observed with $\mathrm{O} 2 \mathrm{~A}^{\mathrm{FRx}}$ cells was likely because of the presence of the dominant-negative FGFRx transgene.

\section{Maintenance of transgene expression in vivo}

Maintenance of the dominant-negative effects of FGFRx would require the stable and continued expression of the fgfrx.nptII transgene in transplanted $\mathrm{O} 2 \mathrm{~A}^{\mathrm{FRx}}$ cells in the absence of G418 selection in vivo. When cultured for $7 \mathrm{~d}$ in the absence of the G418 in vitro, $\mathrm{O} 2 \mathrm{~A}^{\mathrm{FRx}}$ cells continued to maintain high levels of NPTII immunoreactivity, indicating that the transgene was stably integrated and expressed in these cells. These cells also stably expressed the FGFRx transgene in vitro, as determined both by steady-state RNA blot analysis and ligand cross-linking analysis (Fig. 1C). Because reagents to specifically detect murine FGFR1 in rat brain are unavailable, we used anti-NPTII immunohistochemistry to examine transgene expression in $\mathrm{O} 2 \mathrm{~A}^{\mathrm{FRx}}$ cells. In the expression vector used in this study, the $f g f r x$ transgene is bicistronic with and encoded upstream from nptII (Fig. 1A); thus, expression of NPTII from the single promoter in this vector ensures coexpression of FGFRx. At $7 \mathrm{~d}$ after transplantation, PKH26-labeled O2A ${ }^{\text {FRx }}$ cells were identifiable with anti-NPTII antibodies directly lining the ventricles, adjacent to the choroid plexus, and in the ependymal layer as determined by immunohistochemistry (Fig. 5D). Thus the fgfr.nptII transgene expression was maintained in transplanted $\mathrm{O} 2 \mathrm{~A}^{\mathrm{FRx}}$ cells in vivo, suggesting that the phenotype associated with the dominant-negative FGFRx transgene persisted in these grafted cells over the time frame analyzed in this study.

\section{Quantitative analysis of transplanted oligodendrocyte progenitor cells}

The relative distribution of transplanted $\mathrm{O} 2 \mathrm{~A}^{\mathrm{FRx}}$ cells was also examined using immunohistochemical analysis of NPTII, at both 2 and $7 \mathrm{~d}$ after transplantation (Fig. 7). Serial sections from brains that received either of two independent $\mathrm{O} 2 \mathrm{~A}^{\mathrm{FRx}}$ lines were analyzed. After $2 \mathrm{~d}$, a significant number $(21.5 \pm 0.7 \%)$ of $\mathrm{O} 2 \mathrm{~A}^{\mathrm{FRx}}$ cells remained at the site of injection (572 of 2664 cells counted), whereas after $7 \mathrm{~d}$ relatively fewer $(6.0 \pm 8.5 \%)$ were found at the injection site ( 45 of 1077 cells counted). At both time points examined, $<10 \%$ of NPTII-immunoreactive $\mathrm{O} 2 \mathrm{~A}^{\mathrm{FRx}}$ cells were found within the brain parenchyma at a minimum distance of at least two cell diameters from the ventricular space (Fig. 7). The majority of $\mathrm{O} 2 \mathrm{~A}^{\mathrm{FRx}}$ cells identified by NPTII staining were located within the ventricles, accounting for $58 \pm 6 \%$ (1521 of 2664 cells counted) and $84 \pm 11 \%$ (930 of 1077 cell counted) at 2 and $7 \mathrm{~d}$ after transplantation, respectively (Fig. 7). The relative increase in $\mathrm{O} 2 \mathrm{~A}^{\mathrm{FRx}}$ cells within ventricles from 2 to $7 \mathrm{~d}$ may represent a selective loss of NPTII-immunoreactive cells at the injection site; when these cells were excluded from the analysis, the proportion of $\mathrm{O} 2 \mathrm{~A}^{\mathrm{FRx}}$ cells within ventricles at the $2 \mathrm{~d}$ time point represented $73 \%$ of NPTII-immunoreactive cells counted, comparable with that found after $7 \mathrm{~d}$ (Fig. 7). The relatively small

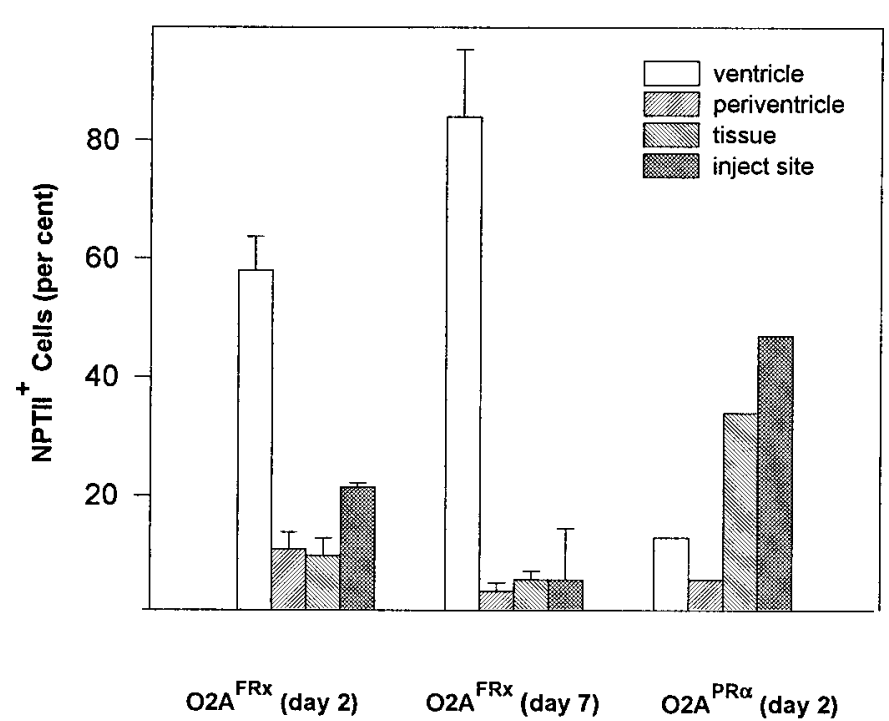

Figure 7. Quantitative analysis of the NPTII-immunoreactive transplanted cells in recipient rat brains. Serial sections from recipients of either pMoFRx-transfected progenitors (two independent lines; $O 2 A^{F R x}$; mean $\pm \mathrm{SD}$ ) or progenitor cells transfected with a control vector $\left(O 2 A^{P R \alpha}\right)$ were examined by NPTII immunohistochemistry at either 2 or $7 \mathrm{~d}$ after transplantation. Values represent the number of cells counted in each location relative to the total number of cells counted for each of the indicated time points. The periventricle was defined as the area within two cell diameters from the ventricular space. Mutant cells were found predominantly within the ventricles, whereas clonally derived control lines expressing NPTII were found within brain parenchyma over the same time course.

decrease in $\mathrm{O} 2 \mathrm{~A}^{\mathrm{FRx}}$ cells located within the parenchyma, from day $2(10 \pm 2.8 \%)$ through to day $7(6.0 \pm 1.4 \%)$ after transplantation, suggested that there was no appreciable difference in the survival of cells located in these separate compartments. Thus this analysis suggests that the primary defect of $\mathrm{O} 2 \mathrm{~A}^{\mathrm{FRx}}$ cells is a lack of migration into brain parenchyma.

This distribution of transplanted $\mathrm{O} 2 \mathrm{~A}^{\mathrm{FRx}}$ cells was in sharp contrast to the behavior of other populations of NPTIIimmunoreactive oligodendrocyte progenitor cells $\left(\mathrm{O} 2 \mathrm{~A}^{\mathrm{FR} 1}\right.$, $\mathrm{O} 2 \mathrm{~A}^{\mathrm{PR} \alpha}$ ). The behavior of control transfectants (Fig. 7) paralleled that of the untransfected parental progenitors. At $48 \mathrm{hr}$, a significant proportion of NPTII-immunoreactive $\mathrm{O} 2 \mathrm{~A}^{\mathrm{PR} \alpha}$ cells (34\%) had migrated away from the injection site into axonal tracts, whereas relatively few $(13 \%)$ remained within the ventricles (93 of 723 NPTII-immunoreactive cells counted). The comparable pattern of migration observed with control transfectants and parental progenitor cells indicated that the clonal selection process used to generate oligodendrocyte progenitor cells in vitro did not affect their ability to migrate in vivo. Thus, the specific lack of migration of $\mathrm{O} 2 \mathrm{~A}^{\mathrm{FRx}}$ cells was likely because of the overexpression of the truncated FGF receptor and suggests this is a result of the disruption of FGF signaling in these cells.

\section{DISCUSSION}

Fibroblast growth factor is one of a large number of polypeptide growth factors that, either individually or in combination, affect the proliferation, migration, survival, and differentiation of oligodendrocyte progenitor cells in vitro (McMorris and McKinnon, 1996). FGF-2 is both a mitogen (Bogler et al., 1990; McKinnon et al., 1990) and survival factor for oligodendrocyte progenitors 
(Yasuda et al., 1995) and induces mature oligodendrocytes to dedifferentiate and re-enter the cell cycle (Fressinaud et al., 1993; Grinspan et al., 1993; Muir and Compston, 1996). The present study demonstrates that a principal requirement of FGF signaling in vivo is during the migration of oligodendrocyte progenitor cells. By introducing a dominant-negative version of the murine FGF receptor FGFR1 into oligodendrocyte progenitors, clonally derived cells were generated that were unable to respond to FGF-2 in vitro. When transplanted into neonatal rodent brain, these cells failed to migrate into brain parenchyma. The failure of mutant cells to migrate was independent of clonal selection and was specific to cells expressing the dominant-negative FGF receptor transgene. Our results are therefore consistent with a model in which FGF signaling is required for oligodendrocyte progenitors to acquire a migratory-competent phenotype in vivo.

At the time of transplantation in this study, endogenous oligodendrocyte progenitors are migrating from the subventricular zone into brain parenchyma (Altman, 1966; Paterson et al., 1973; Levine and Goldman, 1988; Hardy and Reynolds, 1991). When grafted into this environment, wild-type oligodendrocyte progenitor cells are able to respond to local environmental cues including signals for migration and maturation into differentiated oligodendrocytes (Duncan and Milward, 1995; Franklin and Blakemore, 1995). Because mutant cells would be subject to these same environmental cues after transplantation, their phenotype reflects a cell autonomous defect. The inability of $\mathrm{O} 2 \mathrm{~A}^{\mathrm{FRx}}$ cells to migrate under these conditions (Figs. 4,5) implies a role for an FGF ligand-receptor signaling pathway in oligodendrocyte progenitor cell migration in vivo. This is in agreement with recent observations describing a role for FGF in progenitor cell migration in vitro (Milner et al., 1997). These findings are also consistent with the observation that the FGF receptor homolog breathless is essential for migration of specific midline glial cells in Drosophila (Klambt et al., 1992). FGF has not been implicated previously in the chemotactic migration of oligodendrocyte progenitor cells in vitro (Armstrong et al., 1990) but has been shown to prime these cells to respond to PDGF (McKinnon et al., 1993a). Our results thus illustrate the benefits of investigating signal transduction pathways under in vivo conditions, in which the complexity and interplay of biological responses can reveal functions that are not uncovered by in vitro analyses.

The cells examined in this study were amplified in vitro in the presence of mitogens from neuroblastoma B104-conditioned medium. Although this system is accessible to molecular genetic manipulations, it is also subject to the limits of an in vitro approach including the potential to either select for or generate immortalized cells. Because the cells we have examined were isolated from neonatal rodent brain, they would be expected to have a longevity somewhat in excess of the $50 \pm 10$ doublings defined for presenescent adult human fibroblasts (Hayflick, 1965). In the present studies, we have focused on cultures that have been expanded for $<15$ passages (1:3 split ratio) and that are able to differentiate into mature oligodendrocytes both after mitogen withdrawal in vitro and after transplantation in vivo. We have found that at later passages these cell populations can acquire both a mitogen independence for cell proliferation and the inability to differentiate into mature oligodendrocytes after removal of mitogens. However, the early passage cell strains examined in this study did not exhibit these characteristics in vitro and did not have a high mitotic index in vivo, because $<3 \%$ of $\mathrm{PKH} 26$-labeled cells could be detected by immunohistochemistry with antibodies to BrdU. The cells examined in this study thus do not meet the criteria for immortalized or tumorigenic cell lines.

The most straightforward interpretation of this study is that oligodendrocyte progenitor cells expressing a dominant-negative FGFR1 transgene are defective in cell migration. This study does not entirely exclude a possible defect in the survival of $\mathrm{O} 2 \mathrm{~A}^{\mathrm{FRx}}$ mutant cells that have migrated into the host tissue. It is possible, for example, that $\mathrm{O} 2 \mathrm{~A}^{\mathrm{FRx}}$ cells persist within the ventricles because the choroid plexus provides sufficient quantities of factors such as IGF (Stylianopoulou et al., 1988), a potent survival factor for cells of this lineage (Barres et al., 1992, 1993). O2A ${ }^{\text {FRx }}$ cells that migrated into tissue, in contrast, may fail to survive because of their inability to respond to FGF, which promotes oligodendrocyte survival in vitro (Yasuda et al., 1995). However, several observations suggest that the primary defect of $\mathrm{O} 2 \mathrm{~A}^{\mathrm{FRx}}$ cells may not be cell survival. First, the ability to expand mutant oligodendrocyte progenitor cells lacking FGF signal transduction indicates that FGF signaling is not essential for the survival of these cells in vitro. Second, the cotransplantation of parental and mutant cells revealed that $\mathrm{O} 2 \mathrm{~A}^{\mathrm{FRx}}$ mutants persisted for times comparable with that of wild-type progenitors in vivo (Fig. 4A). Third, a quantitative analysis did not reveal a selective loss of transplanted $\mathrm{O} 2 \mathrm{~A}^{\mathrm{FRx}}$ cells located within either ventricles or tissue (Fig. 7). These observations suggest that $\mathrm{O} 2 \mathrm{~A}^{\mathrm{FRx}}$ cells are not defective for cell survival and are thus consistent with the interpretation that the dominant-negative FGFRx transgene affects the ability of oligodendrocyte progenitor cells to migrate in vivo.

The mechanism by which the FGFRx transgene may affect the migration in vivo is not known. The truncated form of FGFR1 acts in a dominant-negative manner to interrupt FGF signaling in these cells (Fig. 2B), implicating altered signal transduction as the primary cause. Oligodendrocyte lineage cells express several forms of FGFRs (Bansal et al., 1996), and because a truncated form of FGFR1 may inhibit signaling by multiple types of fibroblast growth factor receptors (Ueno et al., 1992), O2A ${ }^{\text {FRx }}$ cells should be nonresponsive to any of the FGFs expressed in the CNS. Signaling through the FGF receptor has also be implicated in neurite outgrowth stimulated by the adhesion molecules L1, N-CAM, and N-cadherin (Williams et al., 1994; Saffell et al., 1997). Thus, if cell motility is promoted by cell adhesion molecules acting through the FGF receptor, these interactions may be disrupted in $\mathrm{O} 2 \mathrm{~A}^{\mathrm{FRx}}$ cells. Cell migration can also be regulated by interactions of cells with extracellular matrix molecules via cell surface integrins (Reichardt and Tomaselli, 1991). Oligodendrocyte progenitors express a number of integrins, and the pattern of integrin subunit expression changes as progenitors differentiate into mature oligodendrocytes (Milner and ffrench-Constant, 1994). Because FGF regulates the expression of other cell surface receptors on oligodendrocyte progenitors (McKinnon et al., 1990; Gallo et al., 1994), it is conceivable that integrin expression is also altered in $\mathrm{O} 2 \mathrm{~A}^{\text {FRx }}$ cells. To date, the role of cell adhesion molecules and/or integrins in the migration of oligodendrocyte progenitor cells has not been described. Finally, although the primary focus of expressing a dominant-negative FGFRx transgene is its effects on FGF signal transduction, other possible effects such as altered nuclear translocation of ligand (Bugler et al., 1991; Mason, 1994) could contribute to the inability of these cells to migrate in vivo.

The expression of PDGF by neurons during CNS development (Sasahara et al., 1991; Yeh et al., 1991) is consistent with a role for neuronal PDGF in promoting the migration of oligodendro- 
cyte progenitors along axonal tracts in vivo. Although FGF does not promote chemotactic migration in vitro (Armstrong et al., 1990), one dramatic effect of FGF is the upregulation of PDGFR $\alpha$ expression, leading to an increased sensitivity of these cells to PDGF (McKinnon et al., 1990). Thus, the absence of FGF signaling could affect the ability of these cells to acquire a PDGFresponsive state. Consistent with this, in vitro studies indicate that $\mathrm{O} 2 \mathrm{~A}^{\mathrm{FRx}}$ cells have a slightly decreased mitogenic response to PDGF (Fig. 2A), and initial in vivo analysis indicated that transplanted wild-type cells have a more immature phenotype than do transplanted $\mathrm{O} 2 \mathrm{~A}^{\mathrm{FRx}}$ mutant progenitors (Ebner, unpublished observations). The failure of transplanted $\mathrm{O} 2 \mathrm{~A}^{\mathrm{FRx}}$ progenitors to migrate in vivo could be an indirect result of an impaired response to PDGF, resulting in an inability to adopt the more migratory phenotype in vivo. This model is thus consistent with the observation that transplanted O4-immunoreactive oligodendrocyte progenitors have a decreased migratory ability relative to A2B5-immunoreactive (O-2A) progenitors (Warrington et al., 1993).

The expression of dominant-negative forms of growth factor receptors has proven to be a useful tool for studying the role of growth factor signaling in development. In Xenopus, mesoderm formation is disrupted with dominant-negative forms of both activin (Hemmati-Brivanlou and Melton, 1992) and FGF receptors (Amaya et al., 1991), and a dominant-negative FGFR also causes errors in Xenopus retinal ganglion cell axonal target recognition (McFarlane et al., 1996). Dominant-negative FGF receptors also affect the development of both keratinocytes (Werner et al., 1993) and cardiac myocytes (Mima et al., 1995). By combining ex vivo gene manipulations with cell transplantation, we have been able to address the role of FGF signaling in mammalian CNS development. This approach offers advantages over direct gene transfer in vivo, such as the delivery of receptor transgenes using retroviral vectors (Lillien, 1995) or in vivo transfection (McFarlane et al., 1996), in that we could confirm the dominant-negative effects of the FGFRx transgene in vitro before the analysis of transfected cells in vivo. Our finding that transgene expression was maintained in vivo suggests that this approach may also be useful for sustained overexpression of molecules such as growth factors, which could potentially be used to study repair processes in models of neurological diseases including multiple sclerosis. Thus, ex vivo gene transfer into populations of CNS progenitor cells is an attractive method for studying many aspects of their biology.

\section{REFERENCES}

Altman J (1966) Proliferation and migration of undifferentiated precursor cells in the rat during postnatal gliogenesis. Exp Neurol 16:263-278.

Amaya E, Musci TJ, Kirschner MW (1991) Expression of a dominant negative mutant of the FGF receptor disrupts mesoderm formation in Xenopus embryos. Cell 66:257-270.

Ansubel FM, Brent R, Kingston RE, Moore DD, Seidman JG, Smith JA, Struhl K (1988) Current protocols in molecular biology. New York: Greene and Wiley-Interscience.

Armstrong RC, Harvath L, Dubois-Dalcq M (1990) Type 1 astrocytes and oligodendrocyte-type 2 astrocyte glial progenitors migrate toward distinct molecules. J Neurosci Res 27:400-407.

Baird A (1994) Fibroblast growth factors: activities and significance of non-neurotrophin neurotrophic growth factors. Curr Opin Neurobiol 4:78-86.

Bansal R, Kumar M, Murray K, Morrison RS, Pfeiffer SE (1996) Regulation of FGF receptors in the oligodendrocyte lineage. Mol Cell Neurosci 7:263-275.

Barres BA, Hart IK, Coles HSR, Burne JF, Voyvodic JT, Richardson
WD, Raff MC (1992) Cell death and control of cell survival in the oligodendrocyte lineage. Cell 70:31-46.

Barres BA, Schmid R, Sendnter M, Raff MC (1993) Multiple extracellular signals are required for long-term oligodendrocyte survival. Development 118:283-295.

Barres BA, Lazar MA, Raff MC (1994a) A novel role for thyroid hormone, glucocorticoids and retinoic acid in timing oligodendrocyte development. Development 120:1097-1108.

Barres BA, Raff MC, Gaese F, Bartke I, DeChant G, Barde YA (1994b) A crucial role for neurotrophin-3 in oligodendrocyte development. Nature 367:371-375.

Benvenisty N, Ornitz DM (1995) BK1: an FGF-responsive central nervous system-derived cell line. Growth Factors 12:49-55.

Besnard F, Perraud F, Sensenbrenner M, Labourdette G (1989) Effects of acidic and basic fibroblast growth factors on proliferation and maturation of cultured rat oligodendrocytes. Int J Dev Neurosci 7:401-409.

Bögler O, Wren D, Barnett SC, Land H, Noble M (1990) Cooperation between two growth factors promotes extended self-renewal and inhibits differentiation of oligodendrocyte-type-2 astrocyte (O-2A) progenitor cells. Proc Natl Acad Sci USA 87:6368-6372.

Bugler B, Amalric F, Prats H (1991) Alternative initiation of translation determines cytoplasmic or nuclear localization of basic fibroblast growth factor. Mol Cell Biol 11:573-577.

Canoll PD, Musacchio JM, Hardy R, Reynolds R, Marchionni MA, Salzer JL (1996) GGF/Neuregulin is a neuronal signal that promotes the proliferation and survival and inhibits the differentiation of oligodendrocyte progenitors. Neuron 17:229-243.

Deng C-X, Wynshaw-Boris A, Shen MM, Daugherty C, Ornitz DM, Leder P (1994) Murine FGFR-1 is required for early postimplantation growth and axial organization. Genes Dev 8:3045-3057.

Dubois-Dalcq M (1987) Characterization of a slowly proliferative cell along the oligodendrocyte differentiation pathway. EMBO J 6:2587-2595.

Duncan ID, Milward EA (1995) Glial cell transplants: experimental therapies of myelin diseases. Brain Pathol 5:301-310.

Ernfors P, Lonnerberg P, Ayer-LeLievre C, Persson H (1990) Developmental and regional expression of basic fibroblast growth factor mRNA in the rat central nervous system. J Neurosci Res 27:10-15.

Franklin RJM, Blakemore WF (1995) Glial-cell transplantation and plasticity in the O-2A lineage-implications for CNS repair. Trends Neurosci 18:151-156.

Fressinaud C, Laeng P, Labourdette G, Durand J, Vallat J-M (1993) The proliferation of mature oligodendrocytes in vitro is stimulated by basic fibroblast growth factor and inhibited by oligodendrocyte-type 2 astrocyte precursors. Dev Biol 158:317-329.

Gallo V, Wright P, McKinnon RD (1994) Expression and regulation of a glutamate receptor subunit by bFGF in oligodendrocyte progenitors. Glia 10:149-153.

Gard AL, Pfeiffer SE (1993) Glial cell mitogens bFGF and PDGF differentially regulate development of $\mathrm{O} 4+\mathrm{GalC}-$ oligodendrocyte progenitors. Dev Biol 159:618-630.

Gard AL, Burrell MR, Pfeiffer SE, Rudge JS, Williams WC (1995) Astroglial control of oligodendrocyte survival mediated by PDGF and leukemia inhibitory factor-like protein. Development 121:2187-2197.

Ghattas IR, Sanes JR, Majors JE (1991) The encephalomyocarditis virus internal ribosome entry site allows efficient coexpression of two genes from a recombinant provirus in cultured cells and in embryos. Mol Cell Biol 11:5848-5859.

Gonzalez A-M, Buscaglia M, Ong M, Baird A (1990) Distribution of basic fibroblast growth factor in the 18-day rat fetus: localization in the basement membranes of diverse tissues. J Cell Biol 110:753-765.

Graham FL, Van der Eb AJ (1973) A new technique for the assay of infectivity of human adenovirus 5 DNA. Virology 52:456.

Grinspan JB, Stern JL, Pustilnik SM, Pleasure D (1990) Cerebral white matter contains PDGF-responsive precursors to O2A cells. J Neurosci 10:1866-1873.

Grinspan JB, Stern JL, Franceschini B, Pleasure D (1993) Trophic effects of basic fibroblast growth factor (bFGF) on differentiated oligodendroglia: a mechanism for regeneration of the oligodendroglial lineage. J Neurosci Res 36:672-680.

Hardy R, Reynolds R (1991) Proliferation and differentiation potential of rat forebrain oligodendroglial progenitors both in vitro and in vivo. Development 111:1061-1080.

Hardy RJ, Friedrich Jr VL (1996) Oligodendrocyte progenitors are gen- 
erated throughout the embryonic mouse brain, but differentiate in restricted foci. Development 122:2059-2069.

Hayflick L (1965) The limited in vitro lifetime of human diploid cell strains. Exp Cell Res 37:614-636.

Hemmati-Brivanlou A, Melton DA (1992) A truncated activin receptor inhibits mesoderm induction and formation of axial structures in $\mathrm{Xe}$ nopus embryos. Nature 359:609-614.

Herskowitz I (1987) Functional inactivation of genes by dominant negative mutations. Nature 329:219-222.

Kalcheim C, Neufeld G (1990) Expression of basic fibroblast growth factor in the nervous system of early avian embryos. Development 109:203-215.

Klambt C, Glazer L, Shilo B-Z (1992) Breathless, a Drosophila FGF receptor homolog, is essential for migration of tracheal and specific midline glial cells. Genes Dev 6:1668-1678.

Levine SM, Goldman JE (1988) Spatial and temporal patterns of oligodendrocyte differentiation in rat cerebrum and cerebellum. J Comp Neurol 277:441-455.

Levison SW, Chuang C, Abramson J, Goldman JE (1993) The migrational patterns and developmental fates of glial precursors in the rat subventricular zone are temporally regulated. Development 119:611-622.

Lillien L (1995) Changes in retinal cell fate induced by overexpression of EGF receptor. Nature 377:158-162.

Louis JC, Magal E, Muir D, Manthorpe M, Varon S (1992) CG-4, a new bipotential glial cell line from rat brain, is capable of differentiating in vitro into either mature oligodendrocytes or type-2 astrocytes. J Neurosci Res 31:193-204.

Mason IJ (1994) The ins and outs of fibroblast growth factors. Cell 78:547-552.

Matsui T, Heidaran M, Miki T, Popescu N, La Rochelle W, Kraus M, Pierce J, Aaronson S (1989) Isolation of a novel receptor cDNA establishes the existence of two PDGF receptor genes. Science 243:800-804.

Mayer M, Bhakoo K, Noble M (1994) Ciliary neurotrophic factor and leukemia inhibitory factor promote the generation, maturation and survival of oligodendrocytes in vitro. Development 120:143-153.

McCarthy KD, de Vellis J (1980) Preparation of separate astroglial and oligodendroglia cell cultures from rat cerebral tissue. J Cell Biol 85:890-902.

McFarlane S, Cornel E, Amaya E, Holt CE (1996) Inhibition of FGF receptor activity in retinal ganglion cell axons causes errors in target recognition. Neuron 17:245-254.

McKinnon RD, Zazanis GA (1996) Transplantation of genetically engineered primary cells for the analysis of gene function in CNS development. Methods 10:332-342.

McKinnon RD, Matsui T, Dubois-Dalcq M, Aaronson SA (1990) FGF modulates the PDGF-driven pathway of oligodendrocyte development. Neuron 5:603-614.

McKinnon RD, Smith C, Behar T, Smith T, Dubois-Dalcq M (1993a) Distinct effects of bFGF and PDGF on oligodendrocyte progenitor cells. Glia 7:245-254.

McKinnon RD, Piras G, Ida J, Dubois-Dalcq M (1993b) A role for TGF- $\beta$ in oligodendrocyte differentiation. J Cell Biol 6:1397-1407.

McMorris FA, Dubois-Dalcq M (1988) Insulin-like growth factor I promotes cell proliferation and oligodendroglial commitment in rat glial progenitor cells developing in vitro. J Neurosci Res 21:199-209.

McMorris FA, McKinnon RD (1996) Regulation of oligodendrocyte development and CNS myelination by growth factors: prospects for therapy of demyelinating disease. Brain Pathol 6:313-329.

McMorris FA, Smith TM, Desalvo S, Furlanetto RW (1986) Insulin-like growth factor $1 /$ somatomedin C: a potent inducer of oligodendrocyte development. Proc Natl Acad Sci USA 83:822-826.

Miller RH (1996) Oligodendrocyte origins. Trends Neurosci 19:92-96.

Milner R, Ffrench-Constant C (1994) A developmental analysis of oligodendroglial integrins in primary cells: changes in alpha v-associated beta-subunits during differentiation. Development 120:3497-3506.

Milner R, Anderson HJ, Rippon RF, McKay JS, Franklin RJM, Marchionni MA, Reynolds R, ffrench-Constant C (1997) Contrasting effects of mitogenic growth factors on oligodendrocyte precursor cell migration. Glia 19:85-90.

Mima T, Ueno H, Fischman DA, Williams LT, Mikawa T (1995) Fibroblast growth factor receptor is required for in vivo cardiac myocyte proliferation at early embryonic stages of heart development. Proc Natl Acad Sci USA 92:467-471.
Muir DA, Compston DAS (1996) Growth factor stimulation triggers apoptotic cell death in mature oligodendrocytes. J Neurosci Res 44:1-11.

Noble M, Murray K, Stroobant P, Waterfield MD, Riddle P (1988) Platelet-derived growth factor promotes division and motility and inhibits premature differentiation of the oligodendrocyte/type-2 astrocyte progenitor cell. Nature 333:560-562.

Noll E, Miller RH (1993) Oligodendrocyte precursors originate at the ventral ventricular zone dorsal to the ventral midline region in the embryonic rat spinal cord. Development 118:563-573.

Noll E, Miller RH (1994) Regulation of oligodendrocyte differentiation: a role for retinoic acid in the spinal cord. Development 120:649-660.

Nowakowski RS, Lewin SB, Miller MW (1989) Bromodeoxyuridine immunohistochemical determination of the lengths of the cell cycle and the DNA-synthetic phase for an anatomically defined population. J Neurocytol 18:311-318.

Ornitz DM, Leder P (1992) Ligand specificity and heparin dependence of fibroblast growth factor receptors 1 and 3. J Biol Chem 267:16305-16311.

Ornitz DM, Xu J, Colvin JS, McEwen DG, MacArthur CA, Coulier F, Gao G, Goldfarb M (1996) Receptor specificity of the fibroblast growth factor family. J Biol Chem 271:15292-15297.

Paterson JA, Privat A, Ling EA, Leblond CP (1973) Investigation of glial cells in semithin sections. J Comp Neurol 149:83-102.

Pfeiffer SE, Warrington AE, Bansal R (1993) The oligodendrocyte and its many cellular processes. Trends Cell Biol 3:191-197.

Price J (1994) Glial cell lineage and development. Curr Opin Neurobiol 4:680-686.

Pringle NP, Richardson WD (1993) A singularity of PDGF alphareceptor expression in the dorsoventral axis of the neural tube may define the origin of the oligodendrocyte lineage. Development 117:525-533.

Raff MC, Miller RH, Noble M (1983) A glial progenitor cell that develops in vitro into an astrocyte or an oligodendrocyte depending on culture medium. Nature 303:390-396.

Raff MC, Lillien LE, Richardson WD, Burne JF, Noble MD (1988) Platelet-derived growth factor from astrocytes drives the clock that times oligodendrocyte development in culture. Nature 333:562-565.

Reichardt LF, Tomaselli KJ (1991) Extracellular matrix molecules and their receptors: functions in neural development. Annu Rev Neurosci 14:531-570.

Saffell JL, Williams EJ, Mason JJ, Walsh FS, Doherty P (1997) Expression of a dominant negative FGF receptor inhibits axonal growth and FGF receptor phosphorylation stimulated by CAMs. Neuron 18:231-242.

Sasahara M, Fries JWU, Raines EW, Gown AM, Westrum LE, Frosch MP, Bonthron DT, Ross R, Collins T (1991) PDGF-B chain in neurons of the central nervous system, posterior pituitary, and in a transgenic model. Cell 64:217-227.

Schnurch H, Risau W (1991) Differentiating and mature neurons express the acidic fibroblast growth factor gene during chick neural development. Development 111:1143-1154.

Schubert D, Heinemann S, Carlisle W, Tarikas H, Kimes B, Patrick I, Steinbach JH, Culp W, Brandt BL (1974) Clonal cell lines from the rat central nervous system. Nature 249:224-227.

Small RK, Riddle P, Noble M (1987) Evidence for migration of oligodendrocyte-type 2 astrocyte progenitor cells into the developing rat optic nerve. Nature 328:155-157.

Southern PJ, Berg P (1982) Transformation of mammalian cells to antibiotic resistance with a bacterial gene under control of the SV40 early region promoter. J Mol Appl Genet 1:327-341.

Stylianopoulou F, Herbert J, Soares MD, Efstratiadis A (1988) Expression of the insulin-like growth factor II gene in the choroid plexus and the leptomeninges of the adult rat central nervous system. Proc Natl Acad Sci USA 85:141-145.

Timsit S, Martinez S, Allinquant B, Puelles L, Zalc B (1995) Oligodendrocytes originate in a restricted zone of the embryonic ventral neural tube defined by DM-20 mRNA expression. J Neurosci 15:1012-1024.

Tourbah A, Baron van Evercooren A, Oliver L, Raulais D, Jeanny JC, Gumpel M (1992) Endogenous aFGF expression and cellular changes afer a demyelinating lesion in the spinal cord of adult normal mice: immunohistochemical study. J Neurosci Res 33:47-59. 
Ueno H, Gunn M, Dell K, Tseng Jr A, Williams LT (1992) A truncated form of fibroblast growth factor receptor 1 inhibits signal transduction by multiple types of fibroblast growth factor receptor. J Biol Chem 267:1470-1476.

Warrington AE, Barbarese E, Pfeiffer SE (1993) Differential myelinogenic capacity of specific developmental stages of the oligodendrocyte lineage upon transplantation into hypomyelinating hosts. J Neurosci Res 34:1-13.

Werner S, Weinberg W, Liao X, Peters KG, Blessing M, Yuspa SH, Weiner RL, Williams LT (1993) Targeted expression of a dominantnegative FGF receptor mutant in the epidermis of transgenic mice reveals a role of FGF in keratinocyte organization and differentiation. EMBO J 12:2635-2643.

Williams EJ, Furness J, Walsh FS, Doherty P (1994) Activation of the
FGF receptor underlies neurite outgrowth stimulated by L1, N-CAM, and N-Cadherin. Neuron 13:583-594.

Yamaguchi TP, Harpal K, Henkemeyer M, Rossant J (1994) FGFR-1 is required for embryonic growth and mesodermal patterning during mouse gastrulation. Genes Dev 8:3032-3044.

Yasuda T, Grinspan J, Stern J, Franceschini B, Bannerman P, Pleasure D (1995) Apoptosis occurs in the oligodendroglial lineage, and is prevented by basic fibroblast growth factor. J Neurosci Res 40:306-317.

Yeh HJ, Ruit KG, Wang YX, Parks WC, Snider WD, Deuel TF (1991) PDGF A-chain gene is expressed by mammalian neurons during development and in maturity. Cell 64:209-216.

Yu J-C, Gutkind JS, Mahadevan D, Li W, Meyers KA, Pierce JH, Heidaran MA (1994) Biological function of PDGF-induced PI-3 kinase activity: its role in aPDGF receptor-mediated mitogenic signaling. J Cell Biol 127:479-487. 